\title{
Development and use of quantitative competitive PCR assay for detection of poultry DNA in fish meal $^{*}$
}

\author{
H. Farajollahi, A.A. Aslaminejad, M.R. Nassiry, M.H. Sekhavati, \\ M. Mahdavi ${ }^{1}$ and A. Javadmanesh
}
Department of Animal Science, Faculty of Agriculture, Ferdowsi University of Mashhad P.O. Box 91775-1163 Mashhad, Iran

(Received 30 January 2009; revised version 4 June 2009; accepted 6 November 2009)

\begin{abstract}
In this study we reported the development and evaluation of a quantitative competitive polymerase chain reaction (QC-PCR) for detection and quantification of poultry DNA in fish meal. A universal PCR primer pair (Pou) was used to amplify a specific region 12s rRNA from poultry DNA. Specificity of the primers was evaluated with DNA from cattle and sheep. An external control DNA was constructed by 83 bp differing in length from the poultry target sequence and used for PCR reaction together with the target DNA. DNA was extracted from thirty commercial samples of fish meal and spiked with external control DNA and was co-amplified with Pou primer pair. The signal intensity was quantified by Image J $1.29 \mathrm{x}$ and were used to compare variety of poultry pollution percentage in fish meal samples. The results of QC_PCR showed that pollution percentage was in the range of 0.1 to $3 \%$ in collected samples. This study was the first report of QC_PCR application for quantifying of poultry pollution in fish meal in Iran.
\end{abstract}

KEY WORDS: quantitative competitive PCR, fish meal, poultry DNA, contamination

\section{INTRODUCTION}

Several techniques are currently used for the unequivocal identification of materials from different biological origin in complex mixtures. These methods

\footnotetext{
${ }^{*}$ Supported by Grant from College of Agriculture, Ferdowsi University of Mashhad, Iran

${ }^{1}$ Corresponding author: e-mail: Fum.authors@gmail.com
} 
are particularly relevant in forensic applications and in the human and livestock food industries. The fraudulent misdescription of food contents on product labels is a widespread problem, particularly with high added-value products commanding a premium price (Woolfe and Primrose, 2004). There can be intentional or unintentional contamination in the production chain or during processing. In the past few years, different protein-based methods (electrophoretic, chromatographic and immunological techniques) and more recently, DNA-based techniques, have been developed and are currently used for species identification in food and feeds products. Among protein-based methods, capillary electrophoresis (Molina et al., 1999), two-dimensional electrophoresis (Chianese et al., 1990), HPLC (Ferreira and Cacote, 2003) and ELISA (Anguita et al., 1997; Moatsou and Anifantakis, 2003; Hurley et al., 2004) have been widely reported. Although these methods are effective in certain instances, their main drawback is that proteins are denatured during heat and pressure processing, making the detection of the species present in a processed sample more difficult. DNA-based methods have been shown to be particularly powerful in the analysis of processed foods or forensic samples because DNA is less liable to be disrupted than are many proteins, the identification is not dependent on the tissue, and sequence data can be analysed at different levels of specificity, from groups or species to even variants or genetically modified individuals (Lockley and Bardsley, 2000). A variety of DNA-based methods including polymerase chain reaction (PCR) amplification, RFLP mapping and microarray gene chip assay have now been successfully adapted for the detection of food substitution (Peter et al., 2004; Woolfe and Primrose, 2004). However, conventional PCR techniques allow the qualitative detection of different animal species in an admixture, but do not result appropriate to achieve the quantification of a target species in a product (Lopez-Calleja et al., 2006). DNA-based methods developed for a quantitative detection are either based on quantitative competitive PCR (Wolf and Lüthy, 2001), densitometry (Calvo et al., 2002) or real-time PCR procedures (Dooley et al., 2004; Zhang et al., 2006). PCR analysis can be used as a quantitative method if external standards (competitors) are coamplified with the target DNA. Quantitative competitive PCR (QC-PCR) was first described in 1990 (Gilliland et al., 1990). The standard procedure for QC-PCR comprised four steps: 1. DNA extraction, 2. determination of DNA concentration, 3. QC-PCR with defined external DNA standard concentrations, and 4. separation of PCR products by gel electrophoresis (Hubner et al., 1999). It is important to note that QC-PCR can only be used for determination of relative amounts of target and standard if the regression coefficient $\mathrm{r}^{2}$ is better than 0.99 and the slope of the regression line is very close to unity (Raeymaekers, 1993; Hayward-Lester et al., 1995). Since the poultry wastages are significantly cheaper than fish meal, some commercial factories add this protein source particularly feather and foot of poultry wastages 
to the fish meal to improve the protein percentage, whereas the amino acid profiles are considerably decreased. So in this study we tried to introduce a competitive PCR based method to determine the contamination percentage of poultry DNA in fish meal samples which were selected from some companies in the north and south of Iran randomly.

\section{MATERIAL AND METHODS}

\section{Fish meal samples}

Thirty commercial samples of fish meal from some companies in the north and south of Iran were analysed to check poultry DNA pollution. Authentic samples of fish meal were obtained and were verified to be free of poultry DNA pollution by PCR reaction with Pou primer pair.

\section{DNA extraction}

Fish meal samples $(120 \mathrm{mg})$ were transferred into a $1.5 \mathrm{ml}$-microtube separately. One thousand microlitres lysis reagent, $50 \mu 1$ of $0.5 \mathrm{M}$ EDTA, $5 \mu 1$ of $10 \%$ sodium dodecyl sulphate (SDS) and $25 \mu \mathrm{l}$ of $20 \mathrm{mg} / \mathrm{ml}$ proteinase $\mathrm{K}$ were added. The mixture was incubated in $65^{\circ} \mathrm{C}$ over night on a thermomixer, and then $5 \mu 1 \mathrm{RNase}(10 \mathrm{mg} / \mathrm{ml})$ was added to mixture for another $4 \mathrm{~h}$. After digestion, samples were centrifuged at $5000 \mathrm{~g}$ for $20 \mathrm{sec}$. Supernatant $(500 \mu \mathrm{l})$ transferred into a new $1.5 \mathrm{ml}$-microtube. Then DNA was extracted from fish meal samples according to guanidium thiocyanate-silicagel method (Boom et al., 1990). Quality and quantity of DNA were measured by spectrophotometer (Shimadzu, UV, 160a) by taking the optical density at wave lengths of 260 and $280 \mathrm{~nm}$, respectively, that was equal with 1.95 .

\section{Simplex PCR}

A amplification of a $183 \mathrm{bp}$ fragment from poultry DNA (GenBank accession no. NC_1323) was carried out in a total volume of $25 \mu 1$ in $0.5 \mathrm{ml}$ tubes containing 1 unit of Taq DNA polymerase, $200 \mu \mathrm{M}$ of each dNTPs, $2.5 \mathrm{mM} \mathrm{MgCl}$, $2.5 \mu \mathrm{l}$ PCR product $(10 \mathrm{X}), 14 \mu \mathrm{l} \mathrm{ddH}_{2} \mathrm{O}, 3 \mu \mathrm{l}$ DNA and $1.5 \mu \mathrm{l}$ of each primer (5 pM) (Table 1). The cycling condition was as follow: $10 \mathrm{~min}$ at $94^{\circ} \mathrm{C}$ for initial denaturation, 35 cycles of amplification $\left(30 \mathrm{sec}\right.$ at $94^{\circ} \mathrm{C}, 45 \mathrm{sec}$ at $60^{\circ} \mathrm{C}, 45 \mathrm{sec}$ at $72^{\circ} \mathrm{C}$ ), and final extension for $5 \mathrm{~min}$ at $72^{\circ} \mathrm{C}$. PCR products were analysed by gel electrophoresis in a $1.5 \%$ agarose gel and stained by ethidium bromide. 
Table 1. Primers that used for amplification of Competitor and 12s rRNA

\begin{tabular}{|c|c|}
\hline Name & Sequence 5'-3' \\
\hline Pou $F^{1}$ & TGA GAA CTA CGA GCA CAA AC \\
\hline Pou $\mathrm{R}^{1}$ & GGG CTA TTG AGC TCA CTG TT \\
\hline PouLAM F ${ }^{2}$ & tgagaactacgagcacaaacCATTCGCTAATCAGTGGTGG \\
\hline PouLAM R ${ }^{2}$ & gggctattgagctcactgttGTCGTTCGAGTGCTATCTTGG \\
\hline
\end{tabular}

\section{Construction of the poultry DNA competitor}

Competitor was constructed similar to strategies described earlier (Grassi et al., 1994; Schanke et al., 1994; Studer et al., 1998). The competitor (external control) was designed to contain Pou-universal primer binding sequence of $\sim 20$ bp at ends encompassing a phage sequence. It was generated by amplification of the enterobacteria phage lambda DNA (GenBank accession no. NC_1416) with hybrid primers. The $5^{\prime}$ ends of these primers contained a Pou-universal sequence (Table 1). PCR for poultry DNA competitor performed to amplify a $100 \mathrm{bp}$ fragment. DNA competitor differing by $83 \mathrm{bp}$ in length from the poultry target sequence was constructed and used for PCR together with the target DNA. Competitor amplification was carried out in a total volume of $25 \mu 1$ in $0.5 \mathrm{ml}$ tubes containing 1 unit of taq DNA polymerase, $200 \mu \mathrm{M}$ of each dNTPs, $2.5 \mathrm{mM} \mathrm{MgCl} \mathrm{M}_{2}$, $2.5 \mu \mathrm{l}$ PCR product $(10 \mathrm{X}), 17.5 \mu 1 \mathrm{ddH}_{2} \mathrm{O}, 0.5 \mu \mathrm{l}$ lambda phage DNA and 0.75 $\mu \mathrm{l}$ of each primer $(5 \mathrm{pM})$. The cycling condition was as follow: 4 min at $94^{\circ} \mathrm{C}$ for initial denaturation, 35 cycles of amplification $\left(30 \mathrm{sec}\right.$ at $94^{\circ} \mathrm{C}, 30 \mathrm{sec}$ at $56^{\circ} \mathrm{C}, 60$ sec at $72^{\circ} \mathrm{C}$ ), and final extension for $5 \mathrm{~min}$ at $72^{\circ} \mathrm{C}$. PCR products were analysed by gel electrophoresis in a $1.5 \%$ agarose gel and stained by ethidium bromide. To provide competitor and different dilutions of competitor, $100 \mathrm{bp}$ PCR products from agarose gel was purified by using of kit Diatom DNA Elution (Moscow, Russia). Different dilutions of $10^{-1}$ to $10^{-10}$ were prepared from competitor. The PCR products were quantified by photographing agarose gels with Polariod 665 film (Polaroid, St. Albans, England), which produce a negative image of the photograph. The negative was scanned with a GS-670 image densitometer (Bio-Rad, Hercules, Calif) and analysed with ImageJ 1.38x software (National Institutes of Health, USA). To correct for differences in the fluorescence of ethidium bromide-stained PCR fragments of different size (Piatak et al., 1993), the intensities of amplified standard control was multiplied by the ratio $183 / 100$. 


\section{Quantitative_competitive PCR}

Competitive PCR by using DNA-template and competitor (different dilutions) was carried out in a total volume of $25 \mu \mathrm{l}$ in $0.5 \mathrm{ml}$ tubes containing 1 unit of taq DNA polymerase, $200 \mu \mathrm{M}$ of each dNTPs, $2.5 \mathrm{mM} \mathrm{MgCl}, 2.5$

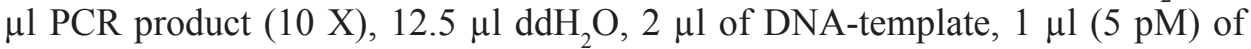
competitor and $2 \mu \mathrm{l}(5 \mathrm{pM})$ of each primer (Table 1$)$. The cycling condition was as follow: $10 \mathrm{~min}$ at $94^{\circ} \mathrm{C}$ for initial denaturation, 35 cycles of amplification (30 sec at $94^{\circ} \mathrm{C}, 45 \mathrm{sec}$ at $60^{\circ} \mathrm{C}, 45 \mathrm{sec}$ at $72^{\circ} \mathrm{C}$ ), and final extension for $5 \mathrm{~min}$ at $72^{\circ} \mathrm{C}$. PCR products were analysed by gel electrophoresis in a $1.5 \%$ agarose gel and stained by ethidium bromide.

\section{Optimizing the suitable dilutions of competitor}

For determination of suitable dilutions, ten separate competitive PCR reactions were performed with all different dilutions from $10^{-1}$ to $10^{-10}$. Electrophoresis analysis denoted that suitable dilutions for competitor PCR were of $10^{-2}$ to $10^{-5}$, because poultry DNA in fish meal samples in these four dilutions with competitor was compared (Figure 1).

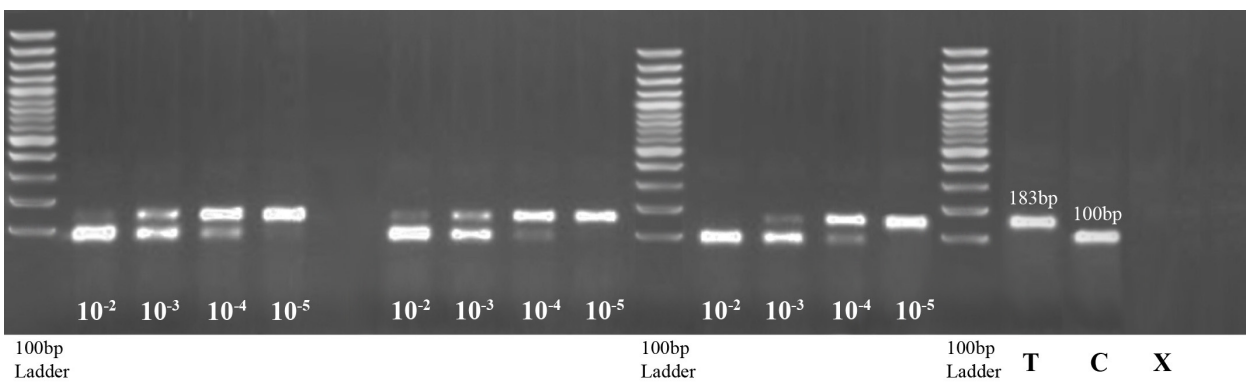

Figure 1. QC_PCR for three different samples of fish meal in four different dilutions $\left(10^{-2}\right.$ to $\left.10^{-5}\right)$ of competitor. T is Target DNA, C is competitor DNA and X is PCR negative control

\section{Determination of standard equation}

To determine the density of contamination in samples, standard equation by using of authentic samples was obtained. After DNA extraction, authentic samples were contaminated in five different percent, contain $10,1,0.1,0.01$ and $0.001 \%$ by using of poultry pure DNA. Competitive PCR for artificial contaminated samples were performed (Figure 2). 


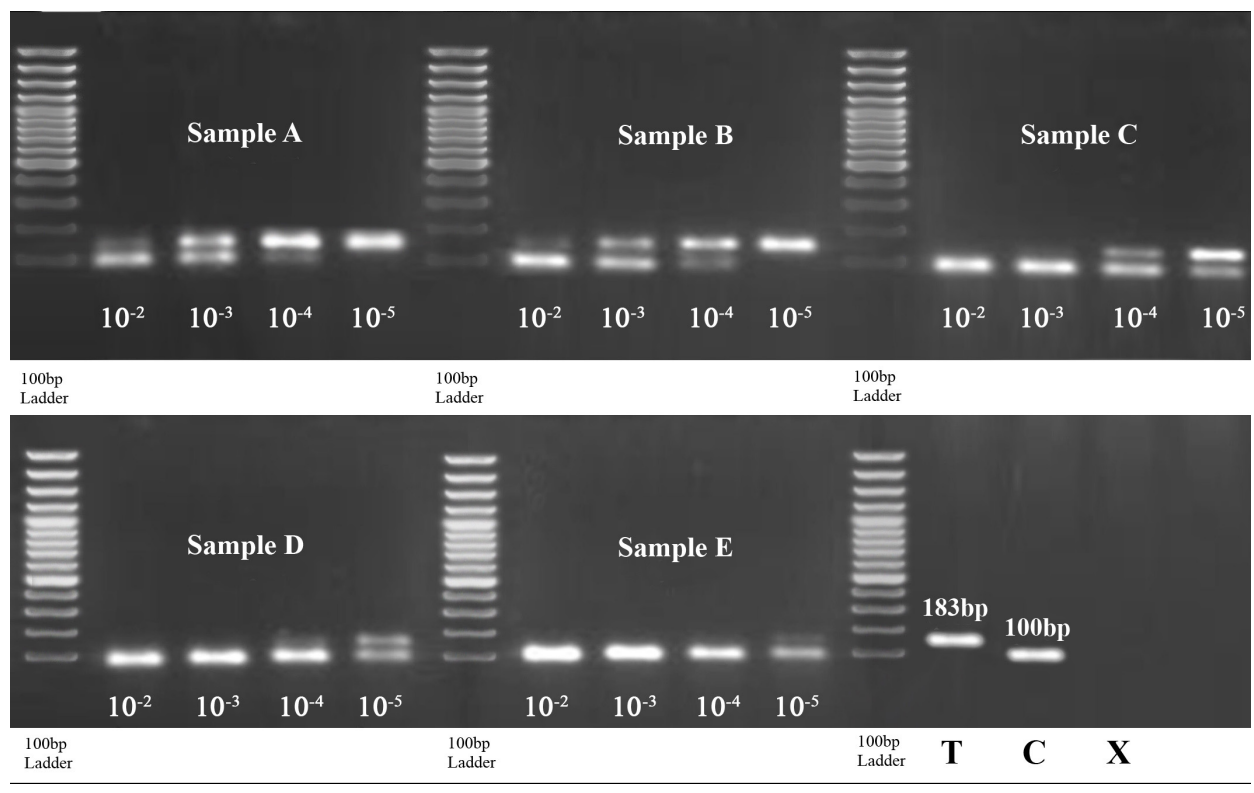

Figure 2. QC_PCR for artificial contaminant samples in four different dilutions $\left(10^{-2}\right.$ to $\left.10^{-5}\right)$ of competitor. A, B, C, D and E, 10, 1, 0.1, 0.01 and $0.001 \%$ contaminated samples, respectively. With decreasing the percentage of artificial contamination (from A to $\mathrm{E}$ ) in each dilution, the intensity of competitor band has been increased because in QC-PCR reaction with reduction of poultry DNA the chance of competitor's amplification would be increased. T is target DNA, C is competitor DNA and $\mathrm{X}$ is PCR negative control

Standard equation by using the intensity of $\log$ (target/competitor) bands which obtained with ImagJ software from artificial contaminant samples was obtained by using JMP software (ver 7.0, SAS Institute Inc. USA) (Table 2).

Table 2. Estimation standard equation by using the intensity of $\log$ (target/competitor) bands from artificial contaminant samples

\begin{tabular}{lcccc}
\hline $\mathrm{Y}$ & $\mathrm{X}_{1}$ & $\mathrm{X}_{2}$ & $\mathrm{X}_{3}$ & $\mathrm{X}_{4}$ \\
\hline 215 & -0.35905 & 0.21146 & -0.99954 & 1.013845 \\
21.5 & -0.52745 & -0.11317 & 0.401545 & 0.779164 \\
2.15 & -0.57816 & -0.61215 & -0.19836 & 0.280267 \\
0.215 & -0.80544 & -0.67635 & -0.36399 & 0.005521 \\
0.0215 & -0.85351 & -0.99954 & -0.85608 & -0.53789 \\
\hline $\mathrm{Y} .215,21.5,2.55$
\end{tabular}

Y: $215,21.5,2.15,0.215$ and 0.0215 , the concentrations of pure poultry DNA $(\mu \mathrm{g} / \mathrm{ml})$ for 10,1 , $0.1,0.01$ and $0.001 \%$ contaminated samples, respectively

$\mathrm{X}_{1}, \mathrm{X}_{2}, \mathrm{X}_{3}$ and $\mathrm{X}_{4}$, the intensity of $\log$ (target/competitor) bands for $10^{-2}, 10^{-3}, 10^{-4}$ and $10^{-5}$ dilutions of competitor, respectively

$$
\mathrm{Y}=80.4806+166.1138 \mathrm{X}_{2}-99.2988 \mathrm{X}_{3} \text {; equation accurate: } \mathrm{r}^{2}=0.96
$$


Note: $\mathrm{r}^{2}$ in introduction is the slope of the regression line between serial dilutions and $\log$ (target/competitor) that in Figure 3 is observable, but $r^{2}$ in equation is equation accurate.

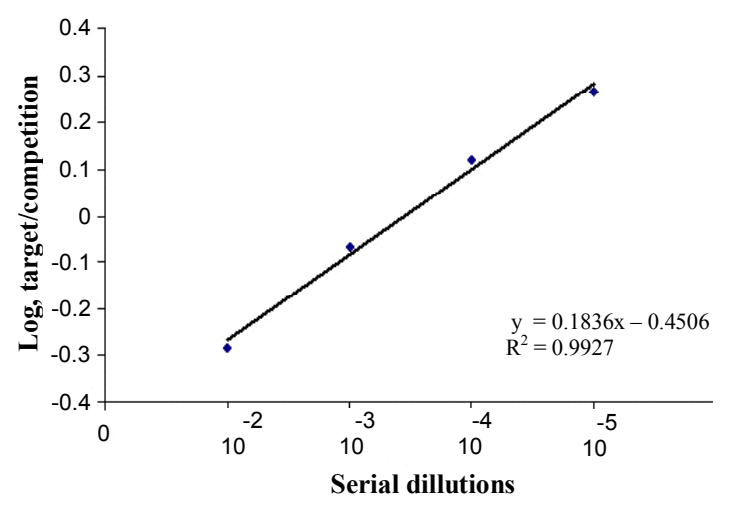

Figure 3. Plotting the mean intensity of log (target/competitor) for each serial dilution. Each point is consisting $19 \mathrm{PCR}$ reactions for each serial dilution

\section{RESULTS}

Simplex PCR reactions for thirty different samples of fish meals denoted that nineteen samples were contaminated with poultry residuals. For these samples, competitive PCR reactions were performed with four suitable dilutions $\left(10^{-2}\right.$ to $\left.10^{-5}\right)$. The samples that specific poultry band $(183 \mathrm{bp})$ were not detected in PCR reactions were used for authentic samples of fish meal. The relative intensities of the PCR bands originating from the competitor and from the target were measured by ImageJ 1.38x software (National Institutes of Health, USA) and then, the mean intensity of $\log$ (target/competitor) were plotting to each serial dilution (Figure 3).

The concentration of each sample was determined with input the intensity of $\log$ (target/competitor) bands of dilutions $10^{-3}\left(\mathrm{X}_{2}\right)$ and $10^{-4}\left(\mathrm{X}_{3}\right)$ of each sample in standard equation. It is important to note that the concentration of pure DNA of poultry was $2150 \mu \mathrm{g} / \mathrm{ml}$ that measured by means spectrophotometer (Shimadzu, UV, 160a). In attention to the concentration of pure DNA of poultry, correction coefficient for determine contaminant percent of samples was equaled 0.0465. By using samples concentration and correction coefficient, contaminant percent of fish meal samples was obtained for each sample (Table 3). 
Table 3. concentration and percentages for different contamination samples of fish meal

\begin{tabular}{cccccc}
\hline Samples & $\begin{array}{c}\text { Concentration } \\
\mu \mathrm{g} \mathrm{m}^{-1}\end{array}$ & $\%$ & Samples & $\begin{array}{c}\text { Concentration } \\
\mu \mathrm{g} \mathrm{m}^{-1}\end{array}$ & $\%$ \\
\hline 1 & 2.85 & 0.13 & 11 & 39.45 & 1.8 \\
2 & 16.59 & 0.77 & 12 & 57.46 & 2.6 \\
3 & 34.50 & 1.6 & 13 & 64.65 & 3.0 \\
4 & 32.29 & 1.5 & 14 & 37.45 & 1.7 \\
5 & 21.07 & 0.98 & 15 & 27.13 & 1.2 \\
6 & 6.13 & 0.28 & 16 & 39.47 & 1.8 \\
7 & 26.96 & 1.2 & 17 & 25.35 & 1.1 \\
8 & 39.95 & 1.8 & 18 & 11.84 & 0.55 \\
9 & 62.10 & 2.8 & 19 & 7.53 & 0.3 \\
10 & 25.87 & 1.2 & & & \\
\hline
\end{tabular}

\section{DISCUSSION}

At present, a critical point concerning the observance of European Union ban of animal meals in feeds is represented by the reliability of the control tests. The possibility of detecting lower levels of animal DNA in feeds would be interesting from a theoretical point of view, but not helpful in practice. In fact, in case of very small amounts of contaminating animal materials, it could be difficult to establish whether a fraud is presumable or an unintentional contamination occurred. This drawback could be overcome by means of a quantitative PCR. In this study we tried to introduce and develop a quantitative PCR-based method with reliable accuracy and appropriate efficiency for quantifying the poultry pollution DNA in unknown fish meal samples. PCR amplification of poultry DNA using the universal PCR primer pair (Pou) produced specific amplicons of the expected size which was previously designed by Dalmasso et al. (2003). Appropriate slope and high coefficient determination $\left(\mathrm{R}^{2}=0.99\right)$ of the $\log$ (target/comperator) with dilutions of the standard control for all contaminated commercial samples (19 samples) indicated that standard control and target DNA amplified with equivalent efficiency in the same reaction and it showed that the synthetic standard control was suitable for the QC-PCR reaction (Figure 3). In the second step we proposed a mathematical approach using multiple regression model to obtain the percentage of the poultry pollution DNA from OC-PCR results. In this regard, one standard model was obtained from known artificial contaminated samples with high coefficient determination $\left(\mathrm{R}^{2}=0.96\right)$. The results showed that this method could detect very small amounts of contaminations $(0.1 \%)$ in mixed DNA samples. Based on our results, this technique could be used to measure the percentage of poultry pollution DNA as a friendly user method with reasonable accuracy. This 
method could be easily used by low budget laboratories for detecting of fraud in commercial fish meal samples in a short period of time.

\section{REFERENCES}

Anguita G., Martin R., Garcia T., Morales P., Haza A., Gonzalez I., 1997. A competitive enzymelinked immunosorbent assay for detection of bovine milk in ovine and caprine milk and cheese using a monoclonal antibody against bovine $\beta$-casein. J. Food Protect. 60, 64-66

Boom R., Sol C.J.A., Salimans M.M.M., 1990. Rapid and simple method for purification of nucleic acids. J. Clin. Microbiol. 28, 495-503

Calvo J.H., Osta R., Zaragoza P., 2002. Quantitative PCR detection of pork in raw and heated ground beef and pate. J. Agr. Food Chem. 50, 5265-5267

Chianese L., Laezza P., Smaldone L.A., Stingo C., Del Giovine L., Addeo F., 1990. Evaluation of bovine milk in the buffalo mozzarella cheese by two-dimensional electrophoresis. Scienza e Tecnica Lattiero-Casearia 41, 315-326

Dalmasso A., Fontanella E., Piatti P., Civera T., Rosati S., Bottero M.T., 2003. A multiplex PCR assay for the identification of animal species in feedstuffs. Mol. Cell. Probes 18, 81-87

Dooley J.J., Paine K.E., Garrett S.D., Brown H.M., 2004. Detection of meat species using TaqMan real-time PCR assays. Meat Sci. 68, 431-438

Ferreira I.M.P.L.V.O., Cacote H., 2003. Detection and quantification of bovine, ovine and caprine milk percentages in protected denomination of origin cheeses by reverse-phase high performance liquid chromatography of beta-lactoglobulins. J. Chromatogr. A 1015, 111-118

Gilliland G., Perrin S., Blanchard K., Bunn H.F., 1990. Analysis of cytokine mRNA and DNA: detection and quantitation by competitive polymerase chain reaction. Proc. Nat. Acad. Sci. USA $87,2725-2729$

Grassi G., Zentilin L., Tafuro S., Diviacco S., Ventura A., Falaschi A., Giacca M., 1994. A rapid procedure for the quantitation of low abundance RNAs by competitive reverse transcriptionpoly- merase chain reaction. Nucl. Acid. Res. 22, 4547-4549

Hayward-Lester A., Oefner P.J., Sabatini S., Doris P.A., 1995. Accurate and absolute quantitative measurement of expression by single-tube RT-PCR and HPLC. Genome Res. 5, 494-499

Hubner P., Studer E., Luthy J., 1999. Quantitative competitive PCR for the detection of genetically modified organisms in food. Food Control 10, 353-358

Hurley I.P., Ireland H.E., Coleman R.C., Williams J.H.H., 2004. Application of immunological methods for the detection of species adulteration in dairy products. Food Sci. Technol. Int. 39, 873-878

Lockley A.K., Bardsley R.G., 2000. DNA-based methods for food authentification. Food Sci. 11, $67-77$

Lopez-Calleja I., Gonzalez I., Fajardo V., Martin I., Hernandez P.E., Garcia T., Martin R., 2006. Quantitative detection of goats milk in sheeps milk by real-time PCR. Food Control 18, 14661473

Moatsou G., Anifantakis E., 2003. Recent developments in antibodybased analytical methods for the differentiation of milk from different species. Int. J. Dairy Technol. 56, 133-138

Molina E., Martin-Alvarez P.J., Ramos M., 1999. Analysis of cows', ewes' and goats' milk mixtures by capillary electrophoresis: quantification by multivariate regression analysis. Int. Dairy J. 9, 99-105 
Peter C., Brünen-Nieweler C., Cammann K., Börchers T., 2004. Differentiation of animal species in food by oligonucleotide microarray hybridization. Eur. Food Res. Technol. 219, 286-293

Piatak M., Luk K.C., Williams B., Lifson J.D., 1993. Quantitative competitive polymerase chain reaction for accurate quantification of HIV DNA and RNA species. Biotechniques 14, 70-80

Raeymaekers L., 1993. Quantitative PCR: theoretical considerations with practical implications. Anal. Biochem. 214, 582-585

Schanke J.T., Quam L.M., Van Ness B.G., 1994. Flip-PCR for DNA sequence motif inversion. Biotechniques 16, 414-416

Studer E., Rhyner C., Luthy J., Hubner P., 1998. Quantitative competitive PCR for the detection of genetically modified soybean and maize. Z. Lebensm. Unters. Forsch. A-Foo 207, 207-213

Wolf C., Lüthy J., 2001. Quantitative (QC) competitive PCR for quantification of porcine DNA. Meat Sci. 57, 161-168

Woolfe M., Primrose S., 2004. Food forensics: Using DNA technology to combat misdescription and fraud. Trends Biotech. 22, 222-226

Zhang C.L., Fowler M.R., Scott N.W., Lawson G., Slater A., 2006. A TaqMan real-time PCR system for the identification and quantification of bovine DNA in meats, milks and cheeses. Food Control 18, 1149-1158 